\title{
PENINGKATAN KETERAMPILAN MENULIS PUISI MELALUI MODEL PICTURE AND PICTURE DENGAN MEDIAGAMBAR PADA SISWA KELAS V SEKOLAH DASAR NEGERI 060890 KECAMATAN MEDAN POLONIA
}

\author{
Zulfaridah \\ Surel: zulfaridah@gmail.com
}

\begin{abstract}
ABSTRAK
Penelitian ini bertujuan meningkatkan prestasi belajar, aktivitas siswa dan keterampilan guru dalam pembelajaran bahasa Indonesia melalui model pembelajaran Picture and Picture dengan Media Gambar. Subjek penelitian adalah siswa kelas V SD N 060890 Medan Polonia yang banyaknya 23 siswa, terdiri dengan siswa laki-laki 12 anak dan siswa perempuan 11 anak. Dari hasil penelitian ini ditemukan bahwa rata-rata hasil belajar yang diperoleh pada pembelajaran matematika melalui model pembelajaran Picture and Picture dengan Media Gambaryakni siklus I 59, Siklus II 66 dan siklus III 74. Sedangkan persentase ketuntasan klasikal yang diperoleh pada setiap siklus adalah siklus I 52\%, siklus II 78\% dan siklus III 86\%. Sedangkan Hasil ratarata aktivitas siswa pada siklus I 2,3 dengan kriteria baik, siklus II 2,8 dengan kriteria baik dan siklus III 3,3 dengan kriteria sangat baik. Rata-rata skor aktivitas guru pada siklus I 35 dengan kriteria baik, siklus II 40 dengan kriteria sangat baik dan siklus III 50 dengan kriteria sangat baik.
\end{abstract}

Kata Kunci: Puisi, Picture and Picture, Media Gambar, Peningkatan Ketrampilan Menulis

\section{PENDAHULUAN}

Kurikulum Tingkat Satuan Pendidikan (KTSP) adalah kurikulum operasi-onal yang disusun oleh dan dilaksanakan di masing-masing satuan pendidikan. Sesuai dengan amanat Peraturan Pemerintah Republik Indonesia Nomor 19 Tahun 2005. standar kompetensi lulusan serta berpe-doman pada panduan dari Badan Standar Nasional Pendidikan Muatan KTSP meliputi sejumlah mata pelajaran yang keluasan dan kedalamannya merupakan beban belajar bagi peserta didik pada satuan pendidikan. Di samping itu materi muatan lokal dan kegiatan pengembangan diri termasuk ke dalam isi kurikulum.

Tujuan mata pelajaran bahasa Indonesia berdasarkan pada muatan Kuriku-lum Tingkat Satuan Pendidikan adalah sebagai berikut: 1) Berkomunikasi secara efektif dan efisien sesuai dengan etika yang berlaku, baik secara lisan maupun tulisan; 2) Menghargai dan bangga menggunakan bahasa Indonesia sebagai bahasa persatuan dan bahasa negara; 3) Memahami bahasa Indonesia dan menggunakan-nya dengan tepat dan kreatif untuk berbagai tujuan; 4) 
Menggunakan bahasa Indo-nesia untuk meningkatkan kemampuan intelektual, serta kematangan emosional dan sosial; 5) Menikmati dan memanfaatkan karya sastra untuk memperluas wa-wasan, memperhalus budi pekerti serta meningkatkan pengetahuan dan kemampuan berbahasa; 6) Menghargai dan membanggakan sastra Indonesia sebagai khazanah budaya dan intelektual manusia Indonesia.

Pembelajaran

Bahasa

Indonesia yang dicapai para siswa masih terbatas pada ketuntasan evaluasi berupa UAS (Ujian Akhir Sekolah) ataupun UASBN (Ujian Akhir Sekolah Berstandar Nasional), yang ditandai dengan siswa lulus dalam mata pelajaran Bahasa Indonesia. Padahal tujuan pembelajaran Bahasa Indonesia yang diakhiri dengan UAS/UASBN belum bias menggambarkan seseorang mahir berbahasa Indonesia dengan baik dan benar. Hal itu dikarenakan UAS ataupun UASBN menggunakan tes objektif, aspek yang diujikan berupa pengetahuan. Oleh karena itu banyak siswa belum bisa menggunakan bahasa yang hakiki, baik bahasa secara reseptif dan secara reproduktif, yang disebut keterampilan ber-bahasa.

$$
\text { Keterampilan berbahasa }
$$

Indonesia mencakup empat aspek, yaitu kete- rampilan menyimak, keterampilan berbicara, keterampilan membaca dan ke- terampilan menulis.
Menulis puisi adalah menuangkan buah pikiran ke dalam bahasa tulis melalui kalimat-kalimat yang dirangkai secara utuh, lengkap dan jelas, sehingga tulisan tersebut dapat dikomunikasikan kepada pembaca secara berhasil. Kemudian keterampilan menulis puisi adalah kemampuan mengungkapkan gagasan, pendapat dan perasaan kepada pihak lain dengan menggunakan bahasa tulis yang bersifat literasi. (Depdiknas, 2003:9)

Dalam pembelajaran menulis puisi ini peneliti menggunakan teknik peng-gunaan model picture and picture dengan media gambar. Metode pembelajaran tersebut yang mengajak siswa untuk mengamati sekumpulan gambar di dalam kelas. Contohnya, siswa diajak mengamati gambar taman, tempat bunga, kupu-kupu, lingkungan alam dan lain-lain. Metode picture and picture juga sangat bermanfaat dalam pembelajaran puisi.

Berdasarkan hasil refleksi awal, dalam pembelajaran puisi di SDN 060890 Medan Polonia masih ditemukan berbagai kendala. Antara lain yaitu guru kurang teram-pil dalam menjelaskan materi tentang menulis puisi. Permasalahan tersebut timbul dari proses pembelajaran menulis puisi pada kelas V SDN 060890 Medan Polonia yang selama ini kurang menggembirakan dan terasa membosankan bagi siswa. Peneliti menemukan berbagai permasalahan yang tim-bul dari guru maupun siswa. 
Dalam pembelajaran menulis puisi guru hanya mem-berikan ceramah mengenai penjelasan-penjelasan tentang puisi. Dan siswa juga kurang tertarik pada penjelasan dari guru karena metode pengajaranya hanya me-lalui ceramah. Hal itu terasa membosankan bagi siswa.

Intinya salah satu faktor utama rendahnya keterampilan menulis puisi pada siswa kelas V SDN 060890 Medan Polonia adalah metode dan media yang digunakan gu-ru dalam pembelajaran kurang tepat. Dengan metode seperti di atas siswa merasa tertekan, sehingga siswa sulit dalam menemukan ide dan kreativitas, dan akhirnya siswa merasa kesulitan dalam menulis puisi dengan kata-kata dan bahasanya sendiri.

Berdasarkan permasalahan tersebut, perlu diupayakan pemecahan nya. Penelitian Tindakan Kelas (PTK) dengan judul "Peningkatan Keterampilan Menulis Puisi Melalui Model picture and pictureDengan Media Gambar Pada Siswa Kelas V SDN 060890 Medan Polonia" diadakan sebagai upaya untuk mening-katkan hasil belajar siswa khususnya keterampilan menulis puisi. Peneliti berpen-dapat bahwa pembelajaran menulis puisi yang awalnya hanya dengan metode ceramah dan penugasan dapat diubah dengan penggunaan model picture and picture dengan media gambar, yaitu siswa diajak guru untuk mengamati sebuah kumpu-lan gambar, kemudian diekspresikan dengan menggunakan kata-kata dan kalimat yang dituangkan dalam sebuah puisi. Kelebihan dari penggunaan model picture and picture dengan media gambar yaitu siswa akan menjadi lebih mudah dalam menulis puisi dan mengekspresikan perasaannya setelah mengamati sekumpulan gambar. Karena banyak contoh gambar yang dapat diamati oleh siswa, misalnya tumbuhan, binatang, alam, bunga, sawah, dan lain-lain yang oleh siswa dapat dituangkan dalam bentuk puisi dengan menggunakan bahasa yang puitis berdasarkan pengamatan serta pengalaman siswa.

Selain itu sesuai dengan penelitian oleh Zulai'i dengan judul "Peningkatan Keterampilan Menulis Puisi Melalui Model Pembelajaran Picture And Picture Siswa Kelas IV SDN". Berdasarkan hasil penelitian yang telah dilaksanakan dalam dua siklus, ternyata hipotesis yang di- rumuskan terbukti kebenarannya. Pembelajaran dengan metode Picture And Picture dapat meningkatkan ketrampilan menulis puisi pada siswa kelas IV SD. Hal ini terbukti hasil belajar siswa menunjukkan ketuntasan klasikal dari $30 \%$ pratindakan menjadi $80 \%$ pada siklus I dan $90 \%$ pada siklus II. Dari data tersebut dapat disimpulkan bahwa penerapan model pembelajaran Picture And Picture dapat meningkatkan keterampilan menulis 
puisi siswa kelas IV SDN.

Berdasarkan latar belakang masalah, maka permasalahan dalam penelitian ini adalah sebagai berikut:

1. Kurangnya tingkat penugasan membaca dan memahami pembelajaran puisi.

2. Setelah ditemukan tema, siswa diajak untuk melihat dan mengamati media gambar. Kemudian siswa diajak berdiskusi tentang hasil pengamatannya.

Untuk memecahkan masalah dari penelitian ini digunakan Penelitian Tindakan Kelas (PTK) dengan menggunakan pengamatan model Picture And Picture dengan media gambar dalam peningkatan kualitas pembelajaran menulis puisi pada siswa kelas V SD Negeri Gunungpati. Langkah-langkah pembelajaran menulis puisi dengan menggunakan pengamatan model picture and picture dengan media gambar adalah:

1. Siswa diberikan contoh puisi anak yang sesuai dengan tema pembelajaran puisi saat itu. Kemudian siswa diminta membaca dan memahaminya.

2. Guru menjelaskan tentang puisi tersebut, mulai dari ciri-ciri objek yang ada dalam puisi tersebut, hingga dapat dituliskan menjadi sebuah puisi. Siswa dijelaskan tentang pengertian puisi, unsur- unsur dan teknik yang digu-nakan dalam penulisan puisi.

3. Guru membawa contoh gambar ke dalam kelas, kemudian menggali penge-tahuan awal siswa terhadap gambar tersebut dengan cara mengajukan per-tanyaanpertanyaan pada siswa tentang gambar tersebut. Hasil jawaban dari siswa dapat diubah ke dalam bentuk kalimat puitis.

4. Siswa menuliskan puisi berdasarkan hasil diskusi sesuai tema yang telah ditetapkan.

5. Peneliti mencatat sejauh mana keterampilan siswa dalam menuliskan puisi menggunakan model picture and picture dengan media gambar, apakah sudah sesuai dengan tema yang diberikan?

Berdasarkan masalah yang telah dirumuskan, maka tujuan penelitian adalah:

1. Meningkatkan keterampilan guru kelas V SDN 060890 Medan Polonia terhadap pem-belajaran menulis puisi dengan menggunakan model picture and picture dengan media gambar.

2. Meningkatkan aktivitas siswa kelas V SDN 060890 Medan Polonia terhadap pem-belajaran menulis puisi dengan menggunakan model picture and picture dengan media gambar.

3. Meningkatkan keterampilan siswa kelas V SDN 060890 Medan 
Polonia dalam menulis puisi dengan menggunakan model picture and picture dengan media gambar.

Penelitian ini bermanfaat dalam pendidikan secara langsung maupun tidak langsung. Manfaatnya antara lain:

1. Sebagai bahan referensi/ pendukung penelitian yang selanjutnya.

2. Untuk menambah pengembangan ilmu mata pelajaran bahasa Indonesia, khususnya menulis puisi.

3. Bagi guru dapat memilih media dan metode yang cocok untuk meningkatkan ke-terampilan menulis puisi.

4. Guru dapat meningkatkan kreativitas siswa.

5. Guru dapat meningkatkan hasil belajar siswa.

6. Bagi sekolah yaitu dapat meningkatkan mutu proses pembelajaran Bahasa Indonesia khususnya menulis puisi.

\section{METODE PENELITIAN}

Penelitian ini dilakukan di SDN 060890 Kecamatan Medan Polonia. Pemilihan tempat ini bedasarkan berbagai pertimbangan, pertimbangan pertama peneliti sebagai guru praktikan di SDN 060890 Kecamatan Medan Polonia. Kedua, sekolah tersebut belum pernah digunakan sebagai objek penelitian yang sama, sehingga terhindar dari penelitian ulang. Ketiga, berdasarkan pengamatan peneliti di SD tersebut terdapat permasalahan dalam

pembelajaran Bahasa Indonesia khususnya menulis puisi. Dan yang keempat peneliti sudah memahami karakteristik siswa yang akan diteliti. Subjek penelitian adalah sumber utama data penelitian yaitu yang memiliki data mengenai variabel yang diteliti (Azwar dalam Alfiah, 2009:31). Subjek penelitian tindakan ini adalah siswa kelas $\mathrm{V}$ terdiri dari siswa perempuan 10 anak dan siswa laki-laki 13 anak, ratarata masih kurang dalam keterampilan menulis puisi. Selain siswa yang dijadikan subjek penelitian, guru juga dijadikan subjek penelitian. Guru yang dijadikan subjek penelitian adalah guru kelas V SD Negeri 060890 Kecamatan Medan Polonia. Penelitian ini merupakan penelitian tindakan kelas, yang dilakukan secara bertahap.

Prosedur penelitian tindakan kelas ini bersumber dari Pedoman Penysunan Usulan PTK yang dikeluarkan oleh Dikti 2004 dan 2005 (Wardhani, 2008:342). Prosedur penelitian terdiri dari skenario pembelajaran, yang gunanya untuk melakukan siklus selanjutnya berdasarkan hasil yang telah dicapai pada siklus terdahulu. Hal ini sebagai langkah-langkah perbaikan dalam pembelajaran. Prosedur penelitian meliputi: 
1. Perencanaan Awal

Sebelum memulai penelitian ini peneliti telah mempersiapkan perencanaan yang akan dilakukan pada saat penelitian ini berlangsung. Perencanaan yaitu tindakan apa yang akan dilakukan untuk memperbaiki dan meningkatkan ke-terampilan menulis puisi. Perencanaan harus dibuat oleh peneliti sebelum peneliti melangkah lebih lanjut. Diantaranya peneliti mempersiapkan jadwal kapan, dimana dan siapa yang akan mengkaji obyek penelitian ini.

\section{Perencanaan Tindakan}

Setelah perencanaan awal, maka langkah selanjutnya yaitu perencanaan tindakan. Dalam perrencanaan tindakan ini peneliti menyusun Rencana Pelak-sanaan Pembelajaran (RPP), mempersiapkan alat peraga yang berupa gambar yang dibawa ke dalam kelas yang akan digunakan sebagai objek dalam pembelajaran menulis puisi menggunakan teknik pengamatan model picture and picture dengan media gambar. Peneliti juga menyiapkan alat evaluasi yang digunakan dalam pembelajaran menulis puisi menggunakan model picture and picture dengan media gambar ini beserta lembar penilaian dan instrumen penelitiannya.

\section{Pelaksanaan Tindakan \\ Pelaksanaan tindakan yang direncanakan hendaknya cukup}

fleksibel untuk mencapai perbaikan yang diinginkan (Alfiah, 2009:32). Untuk menyesuaikan dengan kondisi pembelajaran yang sedang berlangsung, penelitian dilakukan dalam dua siklus. Dalam pelaksanaan tindakan penelitian ini, yang dilakukan peneliti adalah: (1) Siswa diberikan contoh puisi anak yang sesuai dengan tema pembelajaran puisi saat itu. Kemudian siswa diminta membaca dan memahaminya. (2) Guru menjelaskan tentang puisi tersebut, mulai dari ciriciri objek yang ada dalam puisi tersebut, hingga dapat dituliskan menjadi sebuah puisi. (3) Siswa dijelaskan tentang pengertian puisi, unsur-unsur dan teknik yang digunakan dalam penulisan puisi.

Data penelitian ini berupa data kuantitatif dan data kualitatif. Data kuantitatif berupa hasil tulisan puisi siswa kelas V sebelum dilaksanakan dan sesudah di-lakukan penelitian serta penilaian aktifitas guru dalam pembelajaran menulis puisi menggunakan model Picture And Picture dengan media gambar. Sedangkan data kualitatif yang dikumpulkan berupa informasi tentang kete-rampilan, minat, sikap dan motivasi siswa dalam menulis puisi serta semua kegiatan guru dalam pembelajaran menulis puisi menggunakan model Picture And Picture dengan media gambar yang berupa penyusunan rencana pembelajaran. 
Teknik yang digunakan untuk pengumpulan data meliputi observasi/pengamatan, wawancara, kajian dokumen dan tes.

\section{Observasi/pengamatan}

Observasi adalah alat pengumpulan data yang dilakukan dengan cara mengamati dan mencatat secara sistematik gejala-gejala yang diselidiki. Observasi dilakukan secara langsung/tanpa perantara terhadap objek yang diteliti. Observasi dilakukan pada siswa kelas V SD Negeri 060890 Medan Polonia untuk mengetahui minat dan perhatiannya selama proses pembelajaran menulis puisi menggunakan model Picture And Picture dengan media gambar.

\section{Kajian dokumen}

Kajian dilakukan pula pada arsip atau dokumen yang ada. Dokumen tersebut antara lain kurikulum, Rencana Pelaksanaan Pembelajaran (RPP), hasil tulisan puisi siswa, dan daftar nilai.

\section{Tes}

Pemberian tes dimaksudkan untuk mengukur seberapa jauh keterampilan yang diperoleh siswa setelah kegiatan pembelajaran dilakukan. Tes menulis puisi diberikan pada awal kegiatan penelitian untuk mengidentifikasi keku-rangan/kelemahan siswa dalam menulis puisi. Selain itu tes ini akan dilakukan setiap akhir siklus, untuk mengetahui peningkatan hasil tulisan puisi siswa. Hal ini untuk mengetahui tingkat perkembangan keterampilan menulis puisi siswa sesuai siklus yang ada.

4. Wawancara

$$
\text { Wawancara dilakukan }
$$

terhadap guru dan siswa untuk mendapatkan informasi guna memperoleh data yang berhubungan dengan proses menulis puisi menggunakan model Picture And Picture dengan media gambar. Wawancara ini dilakukan sebelum atau sesudah tindakan.

\section{Catatan Lapangan}

Catatan Lapangan merupakan catatan yang dibuat oleh guru segera setelah pembelajaran selesai (Wardhani, 2008:229). Guru dapat mencatat peristiwa-peristiwa penting dalam pembelajaran, seperti partisipasi siswa yang dianggap istimewa, reaksi guru yang menimbulkan berbagai respons dari siswa, atau kesalahan yang dibuat siswa karena guru membuat kekeliruan. Catatan ini akan sangat berharga bagi guru karena merupakan hasil observasi, reaksi, dan refleksi guru terhadap pembelajaran yang dikelolanya. Disamping itu, catatan ini dapat merupakan rekaman perkembangan guru dalam melaksanakan tugas sebagai guru. Catatan lapangan ini terdiri dari tujuan, lokasi, hari dan tanggal, waktu, jenis, 
peneliti, observer, objek penelitian, setting, deskripsi, dan refleksi.

Teknik analisis data yang digunakan adalah sebagai berikut:

\section{Data Kuantitatif}

Data kuantitatif berupa hasil belajar yang mengukur tingkat pemahaman siswa terhadap suatu materi (kognitif). Dalam penelitian ini data kuantitatif berupa kemampuan membaca pemahaman siswa tentang isi bacaan.

\section{Data kualitatif}

Diperoleh dari lembar observasi aktivitas siswa dan keterampilan guru selama proses pembelajaran membaca pemahaman dengan menerapkan strategi Picture and picture. Poerwanti (2008) menerangkan cara untuk mengolah data skor sebagai berikut: (1) Menentukan Skor Terendah, (2) Menentukan Skor Tertinggi, (3) Mencari Median, (4) Membagi Rentang Nilai menjadi 4Kategori (Sangat Baik, Baik, Cukup, Kurang).

\section{HASIL DAN PEMBAHASAN}

Pengamatan pada guru dilakukan untuk mendeskripsikan keterampilan guru dalam mengajar menggunakan strategi menulis puisi menggunakan model Picture And Picture dengan media gambar. Sedangkan pengamatan pada siswa dilakukan untuk memperoleh data aktivitas dan hasil belajar siswa dalam pembelajaran Bahasa Indonesia keterampilan menulis puisi. Peneliti mengamati seluruh siswa kelas V SD 060890. Jumlah siswa yang diamati adalah 23 siswa. Berikut ini adalah uraian tentang pelaksanaan PTK yang telah dilaksanakan.

Berikut deskripsi hasil pengamatan pada siklus I:

1. Hasil Observasi Keterampilan Guru

Peneliti menetapkan 14 indikator keterampilan guru dalam pembelajaran dengan strategi menulis puisi menggunakan model Picture And Picture dengan media gambar. Masing-masing indikator terdiri atas 4 deskriptor.

Keterangan:

$46 \leq$ skor $\leq 56=$ sangat baik,

$35 \leq$ skor $<46=$ baik, $24 \leq$ skor

$<35$ :cukup, dan $14 \leq$ skor

$<24$ : kurang

Dapat diketahui bahwa jumlah skor yang dicapai guru dalam pembelajaran melalui strategi membaca menulis puisi mengguna-kan model picture and picture dengan media gambarpada siklus I adalah sebesar 35 dengan kriteria Cukup pada siklus I keterampilan guru belum mencapai keberhasilan sesuai indikator yang ditetapkan. Oleh karena itu, pada siklus selanjutnya peneliti harus mampu melaksanakan perbaikanperbaikan dalam pembelajaran menggunakan strategi menulis puisi menggunakan model picture and 
picture dengan media gambar.

Adapun deskripsi perolehan skor pada setiap indikator dipaparkan secara rinci dalam uraian berikut:

1) Pengkondisian Kelas. Skor yang diperoleh guru pada siklus I adalah 2. Pada siklus I guru telah melakukan presensi dan mengecek kehadiran siswa. Sebelum memulai pembe-lajaran guru juga memberikan motivasi untuk memusatkan perhatian siswa. Namun dalam pelaksanaan siklus I guru tidak mengatur tempat duduk siswa sebelum pembelajaran berlangsung. Selain itu, pembelajaran dilaksanakan setelah motivasi tanpa menunggu semua siswa tenang dan siap mengikuti pembelajaran di kelas. Sebagian siswa masih gaduh, namun guru tetap saja memulai pembelajaran di kelas.

2) Mempersiapkan Media dan Sumber Belajar. Skor yang diperoleh guru pada siklus I adalah 3. Pada kegiatan pembelajaran guru telah menyiapkan media yang besar dan berwarna menarik, selain itu guru juga menyiapkan sumber dan media belajar yang relevan, namun dalam siklus I guru belum menggunakan multi sumber dalam pembelajaran, sehingga performa guru di depan kelas tampak seperti kurang meyakinkan.
3) Melakukan Apersepsi. Skor yang diperoleh guru pada siklus I adalah 3. Kegiatan apersepsi yang dilakukan oleh guru telah sesuai dengan materi, penjelasan dan contoh yang diberikan mudah dipahami oleh siswa sehingga siswa dapat menanggapi apersepsi yang disampaikan oleh guru. Namun demikian, pada apersepsi dalam pembelajaran siklus I guru tidak memberikan reward yang berkesan pada siswa yang mampu menjawab pertanyaan maupun siswa yang memberikan tanggapan.

4) Memberikan Motivasi dan Penghargaan. Skor yang diperoleh guru pada siklus I adalah 3. Guru sudah memberikanmotivasi dan reward secara verbal dan gestural serta memberikan motivasi berupa yel- yel. Namun, guru belum memberikan reward berupa benda yang sesuai dengan topik untuk lebih memotivasi siswa.

5) Menyampaikan Tujuan Pembelajaran. Skor yang diperoleh guru pada siklus I adalah 3. Guru telah menyampaikan tujuan pembelajaran yang sesuai dengan materi, tujuan pembelajaran disampaikan kepada semua siswa secara lisan dengan jelas dan tegas. Namun demikian, pada siklus I guru tidak menuliskan topik pembelajaran di papan tulis, sehingga siswa yang tidak 
memperhatikan penjelasan dari guru menjadi kesulitan untuk menanggapi penjelasan guru berikutnya. Akibatnya proses pembelajaran multiarah yang diharapkan menjadi tidak tercapai. Membimbing siswa dalam melaksanakan kegiatan mengamati gambar. Skor yang diperoleh guru pada siklus I adalah 2. Guru telah membimbing siswa dalam mengamati gambar siswa. Namun, penjelasan dan pemberian keterangan pada gambar yang disajikan masih sangat kurang.

6) Guru menunjukkan/ memperlihatkan gambar-gambar kegiatan berkaitan dengan materi. Skor yang diperoleh guru pada siklus I adalah 3. Guru telah memberikan contoh gambar. Namun, gambar-gambar yang ada masih kurang menarik per-hatian siswa. Jadi siswa masih sedikit kurang antusias dalam mengikuti pem-belajaran.

7) Guru menunjuk/memanggil siswa secara bergantian memasang/ mengurutkan gambar-gambar menjadi urutan yang logis. Skor yang diperoleh guru pada siklus I adalah 2. Contoh untuk mengurutkan gambar sudah diperlihatkan sebelumnya oleh guru. Namun, contoh tersebut hanya dipahami sebagian siswa saja. Sehingga siswa yang lain ketika mengurutkan gambar masih salah. Dalam kegiatan inipun belum semua siswa mengurutkan gambar dengan benar.

8) Guru menanyakan alasan/dasar pemikiran urutan gambar tersebut Skor yang diperoleh guru pada siklus I adalah 2. Dalam siklus ini, guru telah menanyakan alasan siswa alasan pemikiran urutan gambar tersebut. Namun pertanyaan tidak ditujukan kepada semua siswa, dan hanya pada beberapa siswa tertentu. Dalam pembelajaran pada siklus I, guru juga tidak memancing perta-nyaan dengan

menunjuk

ketidakkonsistenan informasi.

9) Dari alasan/urutan gambar tersebut guru memulai menanamkan konsep/materi sesuai dengan kompetensi yang ingin dicapai. Skor yang diperoleh guru pada siklus I adalah 2. Guru telah menanamkan konsep materi sesuai dengan kompetensi yang ingin dicapai. Namun guru belum membimbing semua siswa dalam pengertian secara merata, serta cara penyampaian dari guru yang kurang menarik. Sehingga banyak siswa yang masih pasif.

10) Membimbing siswa dalam menulis puisi setelah mengamati media gambar. Skor yang diperoleh guru pada siklus I adalah 2 . Untuk membantu siswa dan membimbing siswa dalam menulis 


\begin{abstract}
puisi guru telah
menunjukkan cara yang dapat siswa gunakan untuk menulis puisi dengan baik. Namun pada siklus I guru belum memotivasi siswa untuk lebih bersungguhsungguh dalam menulis puisi. Sehingga dalam proses menulis puisi masih banyak anak yang terlihat mengerjakan asal-asalan.
\end{abstract}

11) Memberikan Kesimpulan. Skor yang diperoleh guru pada siklus I adalah 3. Guru telah menyampaikan kesimpulan sesuai materi, kesimpulan disampaikan secara urut, dan ditujukan kepada semua siswa. Namun, kesimpulan yang disampaikan masih kurang jelas, kalimat yang digunakan oleh guru tidak udah dipahami oleh siswa, sehingga hanya sebagian kecil siswa yang mampu menanggapi kesimpulan yang disampaikan oleh guru.

12) Melakukan Refleksi. Skor yang diperoleh guru pada siklus I adalah 3. Guru telah melakukan refleksi yang ditujukan kepada semua siswa, refleksi disampaikan secara urut sesuai dengan materi yang telah dipelajari, namun, refleksi belum disampaikan secara lengkap.

13) Memberikan Evaluasi. Skor yang diperoleh guru pada siklus I adalah 2. Guru telah memberikan evaluasi mencakup semua indikator dan mengawasi jalannya evaluasi. Namun, guru tidak menyampaikan petunjuk mengerjakan evaluasi dan tidak memberikan evaluasi sesuai alokasi waktu yang ditentukan. Akibatnya siswa tidak memiliki pedoman yang jelas dalam mengerjakan soal evaluasi. Banyak siswa yang kekurangan waktu untuk mengerjakan soal, sehingga beberapa siswa harus mengumpulkan lembar jawab yang belum sepenuhnya terisi.

\section{Pembahasan}

Dari hasil analisis siklus I, II, dan III, maka dapat dinyatakan bahwa model picture and picture dengan media gambar mampu meningkatkan keterampilan mengajar guru di kelas. Keterampilan guru pada siklus I masih dibawah kriteria keberhasilan dengan jumlah skor 35. Pengajaran yang dilakukan guru sudah sesuai dengan alur yang direncanakan. Namun, terdapat beberapa permasalahan yang ditemukan ter-kait kurang terampilnya guru dalam mengelola kelas, mendekati siswa, dan mem-beri pertanyaan.Guru juga dianggap kurang memberikan variasi dalam mengajar. Dijelaskan oleh Suyono, (2011:230) variasi gaya mengajar dan pola interaksi meliputi: (1) varasi suara; (2) pemusatan perhatian; (3) kesenyapan; (4) kontak pandang; (5) gerakan badan; (6) perubahan posisi guru; (7) perubahan 
metode me ngajar; (8) membagi perhatian; (9) penggunaan selingan (ice breaker). Sementara pengelolaan kelas yang dilakukan oleh guru kurang maksimal. Kelas masih sering gaduh, dan banyak siswa yang tidak memperhatikan penjelasan dari guru. Serta keterampilan bertanya pada pembelajaran siklus I masih sangat kurang. Guru memberikan pertanyaan yang umum tanpa memberikan tindak lanjut ke pertanyaan yang lebih khusus atau mengerucut. Dalam setiap kegiatan, guru acapkali lupa memberikan kesempatan pada sisiwa untuk bertanya, dan mengkonfirmasi kejelasan instruksi. Hal ini mengakibatkan kelas tidak terbuka dan siswa pun menjadi enggan mengungkapkan gagasannya. Menurut pandangan Rusman (2010:82) pertanyaan yang tersusun dengan baik dan teknik melontarkan pertanyaan yang tepat akan memberikan dampak positif terhadap aktivitas dan kreativitas siswa.

Sementara pada siklus II memperoleh skor 40 dengan kriteria baik dinyatakan berhasil. Keterampilan mengadakan variasi sudah dilaksanakan de-ngan baik. Sementara keterampilan bertanya masih perlu dikembangkan. Guru masih melupakan pertanyaanpertanyaan kecil seperti mengkonfirmasi kejelasan, dan memberikan kesempatan siswa untuk bertanya. Apabila menerima pertanyaan dari siswa, guru serta merta menjawab. Suyono, mengungkapkan bahwa pertanyaan yang tepat dan efektif sebaiknya dilakukan dengan cara-cara be-rikut: (1) penggunaan pertanyaan secara jelas dan singkat; (2) memberikan acuan yang berupa pertanyaan yang berisi informasi yang relevan dengan jawaban yang diharapkan dari siswa; (3) memusatkan perhatian; menyebarkan giliran menja-wab pertanyaan secara acak; (5) pemberian waktu berpikir.

Pada siklus III memperoleh skor 50 dengan kriteria sangat baik dinyatakan berhasil. Dengan demikian keterampilan mengajar guru dengan menggunakan model picture and picture dengan media gambar sudah terlaksana dengan baik. Keterampilan mengelola kela sudah dilaksanakan dengan mengkondisikan siswa selama pembelajaran.

Selanjutnya keterampilan memberikan variasi terlihat dalam penggunaan media dan gestur yang baik dan mendukung proses pembelajaran. Ini berarti bahwa pengajaran yang dilakukan guru sudah optimal untuk membantu kemajuan siswa. Suyono, (2011:18) mendefinisikan mengajar sebagai suatu proses untuk membantu siswa mencapai kemajuan lebih optimal sesuai dengan tingkat perkembangan potensi kognitif, afektif, dan psikomotorik. Peningkatan keterampilan mengajar guru dalam 
PTK ini juga didukung oleh data hasil wawancara yang peneliti lakukan dengan rekan kolaborator, yaitu wali kelas V SD Negeri 060890.

Kesimpulan dari hasil wawancara guru kepada rekan kolaborator (Guru Kelas V SD Negeri 060890.) bahwa model picture and picture dengan media gambar telah dilaksanakan sesuai dengan pembelajaran menggunakan model picture and picture. Rekan kolaborator menyatakan bahwa model picture and picture sesuai diterapkan pada pembelajaran menulis puisi, karena model picture and picture dengan media gambar ini tidak hanya membantu siswa dalam menulis puisi, namun siswa juga mampu menulis puisi dengan baik dan mudah, tidak seperti pembelajaran sebelumnya yang tidak menggunakan model picture and picture. Guru telah mengajukan pertanyaan yang membangkitkan pengetahuan dan pengalaman siswa, serta membantu siswa merumuskan tujuan pembelajaran.

Selama penelitian, guru selalu memperbaiki kekurangan pada siklus sebe-lumnya untuk siklus selanjutnya sehingga hasil keterampilan guru meningkat. Pada siklus I pembelajaran belum optimal. Pernyataan ini diperkuat oleh hasil observasi keterampilan guru yang belum mencapai kriteria keberhasilan proses sesuai yang ditargetkan.
Persiapan sudah dilaksanakan dengan baik, namun guru masih belum maksimal dalam memberikan variasi, mengelola kelas, dan mengembangkan pertanyaan. Pada siklus II guru melakukan perbaikan dengan menambah sistem pendukung, yaitu media gambar yang lebih kreatif. Kekurangan pada siklus sebelumnya dalam hal pemberian variasi, pengelolaan kelas, dan pemberian pertanyaan berusaha diperbaiki guru. Pada siklus III guru melakukan perbaikan dengan memberikan reward kepada siswa yang aktif di kelas. Langkah ini dinilai sangat efektif untuk meningkatkan aktivitas siswa di kelas. Kekurangan pada siklus sebelumnya dalam hal pemberian pertanyaan diperbaiki dengan menambah intensitas bertanya dan memberikan pertanyaan yang mengerucut.

Dari hasil analisis siklus I, II, dan III, maka dapat dinyatakan bahwa model picture and picture menggunakan media gambar pada pembelajaran Bahasa Indonesia aspek menulis puisi mampu meningkatkan aktivitas siswa. Aktivitas siswa pada siklus I belum memenuhi kriteria yang ditargetkan dengan perolehan rata- rata skor 15.96 dengan kriteria cukup. Hal ini disebabkan oleh beberapa permasalahan yang ditemukan. Yang pertama adalah rendahya budaya berbicara pada siswa. Siswa masih enggan dan malu mengungkapkan gagasannya apalagi bertanya. Hal ini 
dikarenakan ada mitos-mitos pembelajaran yang terjadi sebagaimana dijelaskan oleh Suyono (2011:11) bahwa salah satu mi-tos dalam pembelajaran adalah pembelajar harus pasif, menerima dan mengikuti apa yang diberikan guru.

Pada siklus II mengalami peningkatan dengan perolehan skor rata-rata siswa 22 dengan kriteria baik dan dinyatakan berhasil. Aktivitas berbicara (oral activities) menjadi permasalahan yang kembali muncul di siklus II. Siswa masih ragu dan enggan bertanya apalagi menanggapi meskipun guru sudah memancing dengan bercerita dan memberi kesempatan siswa untuk menanggapi setiap pertanyaan yang diberikan. Padahal Broks \& Brooks dalam Johnson (2011:102) menyatakan, untuk bisa mengerti siswa harus mencari makna. Untuk mencari sebuah makna, siswa harus punya kesempatan untuk membentuk dan mengajukan pertanyaan.

Dan pada siklus III memperoleh skor rata-rata 26.48 dengan kriteria baik dan dinyatakan berhasil. Meskipun demikian masih terdapat kendala pada ak-tivitas berbicara siswa (oral activities). Jumlah siswa yang bertanya meningkat dari siklus sebelumnya, namun masih ada siswa yang pasif di kelas. Dan peneliti menyimpulkan rendahnya kemampuan berbicara siswa adalah sebuah budaya pembelajaran di kelas tersebut atau sudah terjadi sejak kelas- kelas sebelumnya.

Berdasarkan hasil pengisian angket oleh siswa kelas V SDN Gunungpati maka peneliti menyimpulkan bahwa sebagian besar siswa mampu menerima pembelajaran yang guru laksanakan di kelas. Mereka menganggap model pembelajaran Picture And Picture sebagai strategi yang tepat untuk meningkatkan keterampilan membaca pemahaman mereka. Pertanyaan-pertanyaan yang guru sampaikan mampu mereka pahami dengan baik. Dengan kemasan yang menarik dan reward yang tepat, pembelajaran picture and picture menjadi menarik bagi siswa. Namun demikian, ada 5 siswa yang masih pasif di kelas. Tidak mau menanggapi pertanyaan dari guru, dan menganggap pertanyaan dari guru sulit untuk dipahami.

Dari penjelasan diatas, dapat ditarik kesimpulan bahwa melalui model picture and picture dengan media gambar siswa menjadi lebih memahami isi bacaan yang dibaca, selain itu pembelajaran membaca melalui model picture and picture dengan media gambar menyenangkan bagi siswa.

Dari hasil analisis siklus I, II, dan III, diperoleh data bahwa keterampilan menulis puisi siswa mengalami peningkatan pada setiap siklusnya. Maka dapat dinyatakan 
bahwa penerapan model picture and picture dengan media gambar mampu meningkatkan keterampilan menulis puisi siswa. Hasil belajar siswa pada siklus I belum memenuhi kriteria keberhasilan dengan persentase ketuntasan sebesar 68\%. Meskipun demikian, nilai rata-rata siswa sudah memenuhi KKM yaitu 66,9. Hasil tersebut diperoleh berdasarkan proses pembelajaran yang dilaksanakan melalui sinergi antara keterampilan gurudan aktivitas siswa.

Pada siklus II mengalami peningkatan dengan persentase ketuntasan $76 \%$ dengan nilai rata- rata siswa 78.1 dan dinyatakan berhasil. Dengan demikian dapat ditarik simpulan bahwa dalam pembelajaran berpusat pada siswa sekalipun, jika keterampilan guru dalam pembelajaran sudah baik, maka respon atau aktivitas siswa pun menjadi semakin baik dan hasil belajar akan meningkat. Dan pada siklus III mengalami peningkatan kembali dengan nilai rata-rata siswa menjadi 82.8 dan persentase ketuntasan sebesar $88 \%$. Persentase ketuntasan tersebut sudah memenuhi kriteria keberhasilan hasil yang ditentukan yaitu $>80 \%$.

Selama penelitian, hasil belajar siswa selalu meningkat di setiap siklusnya. Pada siklus I siswa menulis teks puisi sesuai dengan tema lingkungan sekitar, belum mencapai kriteria keberhasilan yang peneliti tentukan. Selanjutnya, pada siklus II, siswa kembali menulis teks puisi dengan tema pekerjaan, mengalami peningkatan yang baik. Hasil belajar siswa sudah memenuhi kriteria ketuntasan yang peneliti tentukan, namun masih diperlukan perbaikan. Pada siklus terakhir yaitu siklus III, siswa menulis teks puisi dengan tema pahlawan. Hasil yang dicapai sangat memuaskan, yaitu $88 \%$ siswa dinyatakan tuntas dalam belajar.

Hasil penelitian yang telah dipaparkan menunjukkan bahwa hipotesis tindakan yang peneliti angkat telah terbukti kebenarannya. Bahwa penerapan model picture and picture dengan media gambar mampu meningkatkan keterampilan menulis puisi siswa kelas V SDN 060890.

\section{SIMPULAN}

Berdasarkan hasil penelitian mengenai peningkatan keterampilan menulis puisi melalui model picture and picture dengan media gambarpada siswa kelas V SDN 060890, peneliti dapat menarik kesimpulan sebagai berikut:

1. Penerapan model picture and picture dengan media gambar dapat meningkatkan keterampilan guru dalam pembelajaran menulis puisi pada siswa kelas V SDN 060890. Pada siklus I jumlah skor yang diperoleh se-besar 35 dengan kriteria Cukup. Pada siklus II jumlah skor yang diperoleh guru 
adalah 40 dengan kriteria Baik. Pada Siklus III jumlah skor yang di-peroleh guru sebesar 50 dengan kriteria Sangat Baik;

2. Penerapan model picture and picture dengan media gambar dapat me-ningkatkan aktivitas siswa dalam pembelajaran keterampilan menulis puisi. Pada siklus I skor rata-rata sebesar 15.96 dengan kriteria Cukup. Pada siklus II skor rata-rata sebesar 22 dengan kriteria Baik. Pada siklus III rata-rata skor setiap indikator sebesar 26.48 dengan kriteria Sangat Baik;

3. Persentase ketuntasan klasikal hasil menulis puisi adalah $68 \%$ sedangkan 28\%siswa dalam kriteria tidak tuntas. Pada siklus II nilai rata-rata kelas yang diperoleh adalah 78.1 dengan persentase ketuntasan klasikal adalah $76 \%$. Pada siklus III nilai rata-rata kelas yang diperoleh adalah 82,8 dengan persentase ketuntasan hasil menulis puisi adalah $88 \%$.

Untuk

meningkatkan

keterampilan membaca pemahaman siswa kelas $\mathrm{V}$, peneliti memberikan saran-saran berikut kepada:

1. Sebaiknya guru menggunakan keterampilan dasar mengajar secara optimal dan kreatif dalam usaha merancang pembelajaran yang menyenangkan dan bermakna pada mata pelajaran
Bahasa Indonesia, salah satunya dengan menerapkan model picture and picture dengan media gambar;

2. Sebaiknya guru memotivasi dan mengarahkan siswa untuk belajar dengan aktif, antusias, dan kreatif menyalurkan pendapatnya dalam pembelajaran Bahasa Indonesia sehingga hasil belajar akan terus meningkat lebih baik;

3. Model picture and picture dengan media gambardapat meningkatkan hasil belajar siswa sehingga baik diterapkan pada mata pelajaran Bahasa Indonesia pada aspek menulis puisi.

DAFTAR PUSTAKA

Alfiah, dkk. 2009. Pengajaran Puisi. Yogyakarta: Pustaka Pelajar.

Aminuddin. 2009. Pengantar Apresiasi Karya Sastra. Bandung: Sinar Baru Algesindo.

Anni, Catharina Tri. 2004. Psikologi Belajar. Semarang: UPT MKK UNNES.

Aqib, Zainal. 2006. Penelitian Tindakan Kelas. Bandung: Yrama Widya.

Arsyad, Azhar. 2004. Media Pembelajaran. Jakarta: Raja Grafindo Persada.

Edyanda N. 2009. Kumpulan PuisiPuisi. Jakarta: UBA Press.

Pradopo, Rachmad Djoko. 2007. Pengkajian Puisi. Yogyakarta: 
Zulfarihah: Peningkatan Keterampilan Menulis ..

Gadjah Mada University

Press.

Rahayu, Minto. 2007. Bahasa

Indonesia di Perguruan

Tinggi. Jakarta: Grasindo.

Siswanto, Wahyudi. 2008. Pengantar

Teori Sastra. Jakarta:

Grasindo.

Sudjana, Nana, dan Ahmad Rivai. 2009. Media Pengajaran. Bandung: Sinar Baru Algesindo.

Suprijono, Agus. 2012. Cooperative

Learning. Yogyakarta:

Pustaka Pelajar Tarigan, Djago.dkk. 2003. Pendidikan Keterampilan Berbahasa. Jakarta: UT. Waluyo, Herman J. 2005. Apresiasi Puisi. Jakarta: Gramedia Pustaka

Umum. 
